INTERNATIONAL JOURN AL OF RESEARCHES IN BIOSCIENCES, AGRICULTURE AND TECHNOLOGY (c) VISHWASHANTI MULTIPURPOSE SOCIETY (G lobal Peace Multipurpose Society) R. No.MH-659/13(N) www.vmsindia.org

\title{
EVALUATION OF SOME PLANT PRODUCTS IN STORAGE AGAINST TROGODERMA GRANARIUM EVERTSIN BAJRA
}

\section{Ash ish Lambat ${ }^{1}$, Vipin Babhulkar ${ }^{2}$, Rajesh Gadewar ${ }^{3}$, Sanjiv Charjan ${ }^{4}$, Prachi Lambat ${ }^{5}$ and Ramesh Parate ${ }^{6}$}

1,3 Sevadal Mahila Mahavidyalaya and Research Academy, Nagpur (MS) 2,4,6 Dr. PDKV's College of Agriculture Nagpur.

5 Shri Mathuradas Mohata Science College, Nagpur

\begin{abstract}
: treatment and control during storage.

\section{Introduction:}

The khapra beetle (Trogaderma granarium Everts) is a serious pest of stored grain causing considerable damage to almost all cereals in storage. It is largely responsible for damage and frequently harboring store, mill and warehouses. Khapra beetle is cosmopolitan in nature attributing about $50 \%$ loss in seed weight during storage.

The steady rise in the use of pesticides for control of store grain pests can be dange rous to human being and cattle as well due to their residual toxicity. With view to find out safe and organic seed protectants, present investigation was taken up to evaluate the organic grain protectants in seed storage against khapra beetle in Bajra.
\end{abstract}

The khapra beetle (Trogoderma grananrium Everts) is a serious store grain pest of wheat during storage. In the present investigation, the experiment was conducted to know the effect of diffe rent organic grain protectants on infestation percentage of khapra beetle and seed qualities of Bajra. It was obse rved that seed treated with sweet flag powder $(2.5 \%)$ and custard apple seed powder $2.5 \%$ were showed significantly higher 100 seed weight, germination percentage, seedling vigour, field emergence percentage and adult mortality as compared to other seed

Keywords : organic grain protectants, sweet flag, custard apple, khapra beetle, Bajra, infestation, storage.

\section{Material and Methods:}

Bajra seed were used in various phages of this study, produced in 2014-2015. The seed were cleaned and dried (moisture content 10.5\%). The Bajra seed we re treated (May 2014) with six plant product viz., Neem leaf, sweet flag, Tulsi, Custard apple, Turmeric and Pongamia powder is in the proportion of $2.5 \%$ by weight of the seeds. The experiment as conducted in glass bottle of 1 lit capacity with seven treatments including untreated control. Each glass bottle was then filled with 500 gm of Bajra seeds. 10 pairs of 2-3 days old khapra beetle were released in each glass bottle covered with muslin cloth. The set of experiment was kept in well ventilated wire mesh almirah in masonry building having cemented walls, roof and floor under ambient temperature (24.1 $\left.45.8^{\circ} \mathrm{C}\right)$ and relative humidity $(20-82 \%)$ from May to July, 2014. After three months the seed from each treatment were keenly observed and those found infested we re separated out weighted to determine the infestation percentage on weight basis hundred seed weight and germination were tested in quadruplicate with 100 seed in each replication. The germination percentage was evaluated on the value for normal seedling (Anon. 1985). The vigour index were workout following the method of Abdul Baki and Anderson (1973). For field emergence test, sowing of Bajra seed was one in randomized block design, with four replication with inter and intra row spacing of one feet and six inches respectively. Observations for field emergence were recorded daily and finally the established seedlings were counted after one month of sowing. The experimental data was statistically scrutinized as per the Panse and Sukhatme (1967)

\section{Result and Discussion:}

The data regarding the effect of the different organic grain protectants on population behavior(Adult mortality), infestation percentage 100 seed weight, germination pe rcentage, vigour index and field emergence percentage after th ree months of storage are given in table 1 .

The re sult indicated that variation in number of khapra beetle (adult) in each treatment. The khapra beetel adult mortality was significantly highest in Bajra seed treated with sweet flag $(90 \%)$ which is closely followed by custard apple (88\%) neem leaf (52\%), pongamia (51\%), tulsi $(49 \%)$ and turmeric $(46 \%)$. Whe re in significantly lower mortality was observed in untreated control (5\%). Saxenaet. Al (1976), Tikku et al. (1978) and Khan and Borle (1985) found Acorus calamus $\mathrm{L}$ oil vapour responsible for causing infecundity among the female of a number stored grain pest. Biradar (2000) who reported that sweet flag has got insecticidal and ovicidal 
effect. The significantly maize seed weight loss was observed in untreated control followed by turmeric, tulsi, pongmia, neem leaf, custard apple and sweet flag treatment during entire period of storage. This might be due to sterilizing effect of sweet flag rhizome powder mixed with maize seeds. Charjan and Tarar (1994), Deshpande et al. (2010), Ashish et al. (2011), and K. Cherian et al. (2011) reported that the sharp declined in infe station percentage of store grain pest in seed treated with Acorus calamus powder.

Table-1: The Effect of different organic protectants on khapra beetle mortality, infestation percentage, 100 seed weight, germination percentage, seedling vigour and field eme rgence percentage.

\begin{tabular}{|c|c|c|c|c|c|c|}
\hline Treatments & $\begin{array}{c}\text { Adult } \\
\text { Mortality (\%) }\end{array}$ & $\begin{array}{c}\text { Pre vent weight } \\
\text { loss due to } \\
\text { infestation (\%) }\end{array}$ & $\begin{array}{c}100 \text { seed } \\
\text { weight }\end{array}$ & $\begin{array}{c}\text { Germination } \\
(\%)\end{array}$ & $\begin{array}{c}\text { SVI } \\
\text { emergence } \\
(\%)\end{array}$ \\
\hline Neem Leaf (2.5\%) & 52 & 5.6 & 1.02 & 80 & 1770 & 70 \\
\hline Sweet flag (2.5\%) & 90 & 1.4 & 1.44 & 91 & 3112 & 82 \\
\hline Tulsi (2.5\%) & 49 & 6.1 & 1.10 & 79 & 1708 & 69 \\
Custard apple (2.5\%) & 88 & 1.8 & 1.39 & 90 & 3007 & 81 \\
\hline Turme ric (2.5\%) & 46 & 6.6 & 1.27 & 77 & 1689 & 67 \\
\hline Pongamia (2.5\%) & 51 & 5.4 & 1.31 & 80 & 1751 & 70 \\
\hline Untreated control & 5 & 15.12 & 0.89 & 25 & 688 & 10 \\
\hline SEm (+) & 0.29 & 0.06 & 0.02 & 0.10 & & 0.08 \\
\hline CD at 5\% & 0.90 & 0.17 & 0.07 & 0.30 & & 0.25 \\
\hline
\end{tabular}

The seed quality parameters viz., 100 seed weight, germination percentage and seedling vigour index was highest in seed treated with $2.5 \%$ concentration of sweet flag powder followed by custard apple, neem leaf, pongamia, tulsi, turmeric and untreated control. The 100 seed we ight, germination percentage and vigour index decreased with increasing infestation fo stored grain pest Howe, (1972), Charjan and Tarar (1994), Deshpande et al. (2010) and Ashish Lambat et al (2011). Since the stored grain pest have been eaten off major portion of the endosperm which leads to reduction in we ight of the maize seeds and in turn affect the seed germination and vigour index because of lack of stored food and is in conformity with the findings of Narayanswami (1985). Handerson ad Christensen (1961) reported that pulse beetle attack the embryo and germination potential of seed reduced or totally destroyed.

The field emergence percentage of Bajra seeds follow the same trends of seed quality parameters. The field emergence percentage was highest in seed treated with $2.5 \%$ concentration of sweet flag powder as compared to other treatments and untreated control. This might be due to the least infestation of khapra beetle and higher 100 seedweight, ge rminability and seedling vigor index. The results are agreement to those reported by Charjan and Tarar (1994), Deshpande et al. (2010), AshishLambat et al (2010) and K. Cherianet at (2011).

Among the plant products sweet flag powder $2.5 \%$ were found to be significantly effective against khapra beetle throughout the period of investigation these findings are agreement with Siva Srinivasu (2001), Deshpande et al. (2010), Charjan and Tarar (1994) and Ashish Lambat et al (2011) thus sweet flag and custard apple naturally occurring botanicals which are not toxic can be used as pre storage seed treatment, dispensing with the use of costly and toxic can be used as pre storage seed treatment, dispensing with the use of costly and toxic chemicals to control khapra beetle damage without adversely affecting the germination of maize seed.

\section{References:}

Abdul Baki, A.A. and Anderson J.D. 1973 Vigour determination in soybean seed by multiple criteria. Crop sci. 13: 630-633.

Anonymous, 1985 International rules for seed te sting. Seed Sci. and Technol. 13: 299-513

Ashish Lambat, Rajesh Gadewar, Sanjeev Charjan, Konglath Cherian and Prachi Lambat, 2011.Evaluation of organic grain protectants in seed storage against rice weevil in wheat.Proc. Of International conference on Sustainable Environment held during 19-20 February 2011 at Aurangabad, Maharashtra, India. Special issue $6: 122-123$.

Biradar, B.S. 2000 Preve ntion of cross infestation by Sitophilusoryzae L. and Rhizoperthadominica in stored wheat. M.Sc. (Agri.) Thesis, University of Agricultural Sciences, Dharwd.

Charjan S.K.U.and Tarar, J.L. 1994 The influence of some plant products on seed quality of lobia during storage. Ann. Plant Physiol. 8 (2) L : 153-156

Deshpande, V.K. Desh pande, H.H. and Masuthi, D. 2010 Evaluation of grain protectants in seed storage against Sitophilusoryzae (L.) in sorghum. Green farming 1(5):512-514.

Harderson, L.S. and Christensen, C.M. 1961 Pre harvest control of insect and fungi. U.S. Dept. Agri. Ybk, pp. 348-356. 
Howe, R.W. 1972 Insect attacking seed during storage.Seed Biology vol. III (ed. Kozlowski, T.T.) Academic press: New York pp. 247-300.

Khan, M.I. and Borle, M.N. 1985 Efficacy of some safer grain protectants against the pulse beetle Collosobruchuschenensis L. infecting stored Bengal gram (Cicerarietinum L. ) P.K.V. Res. J 9(1) : 53-55.

Konglath Cherian, Sanjeev Charjan, Vandan Mohod, Ashis Lambat and Rajesh Gadewar 2011.Studies on the influence of Acorusclamus L. rrhizome Powder seed treatments against stored grain pest of wheat.Proc. Of National Seminar on Environmental Management and Biodiversity conservation, held during 26-27 February 2011 at Rishikesh (U.K.) India. Abstract no. A127 page 101.
Narayanaswamy, S 1985 Effect of Pulse bee tle damage on seed quality of field bean and Pigeon pea. Seed Res. 13 (2) : 138-141.

Panse, V.G. and Sukhatme, P.V. 1967. Statistical methods for agricultural workers. I.C.A.R. Pub., New Delhi.

Saxena, B.P., Koul, O. and Tikku, K. 1976. Non toxic protectants against the stored grain insect pest. Bull. Grain Technol. 14(5): 1990-193.

Tikku K., Koul, O. and Saxena B.P. 1978. The influence of Acoruscalamus L. oil vapour on the histocytological pattem of the ovaries of Trogode rmagranarium Evert. Bull. Grain Tehnol. 